\title{
Rевеавсн Автісl: : Influence of tillage and weed management methods on nutrient uptake and yield in maize - sunflower cropping system
}

Article Chronicle:

Received :

11.07.2017;

Accepted :

24.07.2017

KeY WoRdS:

Tillage, Weed management methods, Nutrient

uptake, Yield, Cropping system
SUMMARY : Field experiments were conducted during Rabi and Kharif season of 2012 and 2013 at northern block of Cotton Research Station, Veppantattai, to study the effect of tillage and weed management methods on weeds dynamics and yield of maize -sunflower cropping system under irrigated conditions. The experiments were laid out in strip plot design with three replications. Main plot treatment consisted of three tillage methods viz., conventional tillage, minimum tillage and zero tillage. Five weed management methods viz., pre- emergence application of herbicide (atrazine @ 0.5 $\mathrm{kg} \mathrm{ha}^{-1}$ for maize and pendimenthalin @ $1.0 \mathrm{~kg} \mathrm{ha}^{-1}$ for sunflower) followed by hand weeding on 40 DAS, pre- emergence application of herbicide (atrazine @ $0.5 \mathrm{~kg} \mathrm{ha}^{-1}$ for maize and pendimenthalin @ $1.0 \mathrm{~kg}$ $\mathrm{ha}^{-1}$ for sunflower) followed by power weeding on 40 DAS, hand weeding twice on 20 and 40 DAS, Power weeding on 20 and 40 DAS along with an unweeded check for both the crops consisted as the sub plot treatments. The maize seeds of NK 6240 and sunflower hybrid seed sunbred were sown on 60 x $25 \mathrm{~cm}$. spacing. Recommended fertilizer dose of 250:75:75 kg NPK/ha for maize and 60:30:30 kg NPK / ha for sunflower were applied in the form of urea, single super phosphate and murate of potash. Conventional tillage recorded higher uptake nutrients in Maize - sunflower copping system. Integrated weed management by pre-emergence application of atrazine $0.5 \mathrm{~kg} \mathrm{ha}^{-1}$ for maize and pendimethalin 1.0 $\mathrm{kg} \mathrm{ha}^{-1}$ for sunflower followed by a hand weeding on 40 DAS $\left(\mathrm{M}_{1} \mathrm{~W}_{1}\right)$ for each crop resulted in higher plant dry matter and consequently highest $\mathrm{N}, \mathrm{P}$ and $\mathrm{K}$ nutrients uptake by the plants and leads to higher yield.

How to cite this article : Baskaran, R., Kavimani, R. and Arunvenkatesh, S. (2017).Influence of tillage and weed management methods on nutrient uptake and yield in maize - sunflower cropping system. Agric. Update, 12 (TECHSEAR-2) : 426-430; DOI: 10.15740/HAS/AU/12.TECHSEAR(2)2017/426-430.
Author for correspondence :

\section{R. BASKARAN}

Agricultural College and Research Institute, Eachangkottai, THANJAVUR (T.N.) INDIA

Email: rbaski73@

gmail.com

See end of the article for authors' affiliations 